\title{
Hubungan Kerjasama Tim Perawat Dalam Meningkatkan Budaya Keselamatan Pasien
}

\author{
Riana Silvia Casuarina L.Tobing \\ riana.sct@gmail.com
}

\section{Latar Belakang:}

Keselamatan pasien merupakan salah satu dari enam indikator utama kualitas pelayanan kesehatan di rumah sakit yang merupakan komponen penting dari mutu pelayanan kesehatan serta sebagai komponen kritis dalam manajemen mutu rumah sakit. Peningkatan mutu dan kinerja organisasi rumah sakit harus dilakukan terusmenerus melalui evaluasi dan perbaikan oleh rumah sakit. Setiap organisasi yang akan melakukan perbaikan harus tahu aspek mana yang perlu diperbaiki dan dengan apa upaya perbaikan tersebut . Budaya keselamatan pasien merupakan hal yang penting dalam keselamatan pasien. Membangun budaya keselamatan pasien merupakan suatu cara untuk mewujudkan keselamatan pasien secara keseluruhan. Fokus pada budaya keselamatan pasien akan lebih berhasil apabila dibandingkan hanya fokus pada program keselamatan saja (Fleming , 2006 ; Reason , 2000). Budaya keselamatan pasien secara garis besar dipengaruhi oleh 4 dimensi yaitu terbuka (chea),adil(just) dan informatif dalam melaporkan kejadian yang terjadi( reporting) dan belajar dari kesalahan yang ada ( learnine ).Bersikap terbuka dan adil berart berbagi informasi secara terbuka dars bebas, dan perlakuan adil bagi perawat ketika sebuah kejadian terjadi (NPSA,2004).Informasi yang akurat membantu dalam pencegahan kejadian dari keselamatan pasien . Sistem pelaporan digunakan untuk memberian informasi kepada pihak managerial mengenai kejadian yang terjadi dan sebagai pembelajaran sehingga kejadian yang sama tidak terulang ( Carthey \& Clarke . 2010 ) . Budaya keselamatan pasien juga dapat mengurang pengeluaran financial yang diakibatkan oleh kejadian keselamatan pasien (NPSA 2004) . Menurut Agency of health Research and Quality ( 2004 ) dalam menilai budaya keselamatan pasien di rumah sakit terdapat beberapa aspek atau dimensi yang perlu diperhatikan yaitu Harapan dan tindakan Supervisor / manajer dalam mempromosikan mempromosikan keselamatan pasien. 
pembelajaran berkelanjutan, kerjasama tim dalam unic . kecerbukaan komunikasi , umpan balik terhadap error respon tidak menyalahkan sual yang adekuat, persepsi secara keseluruhan dukungan manajemen rumah sakit penyerahan dan pemindahan pasien dan frekwensi pelaporan kejadian Dalam budaya keselamatan pasien terdapat budaya untuk melaporkan kesalahan ataupun kejadian nyaris cidera . Pelaporan tersebut digunakan sebagai pembelajaran bap organisasi dalam memperbaiki sistem pelayanan, budaya tersebut hanya dapat berkembang dalam suasana yang tidak memojokkan atau memeper salahkan individu sehingga tercipta keterbukaan dan sikap jujur . Mahajan ( 2010 ) menyebutkan factor yang menghambat pelaporan kesalahan medis antara bin adanya hukuman bagi individu yang mengalami kesalahan, budaya keselamatan yang buruk,kurangnya pengertian diantara klinisi tentang apa yang perlu dilaporkan dan bagaimana pelaporan kejadian dapat memberikan manfaat bagi perbaikan system pelayanan . Secara khusus kurangnya analisis yang sistematik dan kurangnya umpan balik menyebabkan keterlibatan yang rendah dari para klinisi dalam pelaporan kejadian Budaya keselamatan pasien merupakan pondasi utama dalam menuju keselamatan pasien . Penerapan ini seplan dengan National Patient Safety Agency dalam tujuh langkah menuju keselamatan pasien juga menekankan bahwa langkah awal menuju keselamatan pasien adalah dengan menerapkan budaya keselamatan pasien tujuh langkah keselamatan pasien yang menekankan bahwa tanglah awal menuju keselamatan pasien adalah dengan menerapkan budaya keselamatan pasien Pentingnya budaya keselamatan di layanan kesehatan juga digarisbawahi oleh Canadian Council on Health Service Accreditation (CCHSA). Budaya Keselamatan pasien merupakan fondasi keselamatan pasien. Membangun budaya keselamatan pasien merupakan kata kunci terwujudnya pelayanan yang bermutu dan aman, terdapat beberapa faktor yang mempengaruhi penerapan budaya keselamatan pasien yaitu salah satunya yaitu kerjasama tim.

\section{Tujuan :}

Untuk mengetahui hubungan kerjasama tim perawat dalam meningkatkan budaya keselamatan pasien, untuk mengetahui dimensi budaya keselamatan pasien di rumah sakit. 


\section{Metode:}

Artikel Ilmiah ini berdasarkan tinjauan sistematik dari beberapa artikel jurnal penelitian yang dipublikasi pada basis elektronik menggunakan metode tersearch dan analisis dari berbagai sumber seperti buku teks, buku referensi jurnal, dan e-book, dengan menggunakan Google Scholar,Portal Garuda dan Jurnal Keperawatan Indonesia. Yang berhubungan dengan hubungan kerjasama tim dalam meningkatkan budaya keselamatan pasien, untuk mengetahui dimensi budaya pasien di rumah sakit. Dari berbagai sumber informasi digunakan untuk mengetahui pengaruh faktor-faktor yang berhubungan.

\section{Hasil :}

Kerjasama tirn antar unit mernpermudah implementasi suatu progl'am kerja dan pelaksanaan hasil tindak lanjut. Penelitian ini menggunakan variabel Kerjasarna tim yang terdiri dari tiga sub variabel yaitu komunikasi dalarn unit, antar unit dan kornunikasi terbuka, kepercayaan atau trust, dan Pembelajaran organisasi dan Perbaikan berkelanjutan. Kemampuan untuk memimpin tim adalah sebuah kualitas fundamental yang dicari sebuah organisasi. Efektivitas kepemimpinan dalam tim dapat dinilai dari berbagai aspek antara lain:

1) Mampu menajamkan pikiran, menyusun misi, visi dan tujuan yang ingin dicapai,

2) Menyusun rencana aksi yang tertulis, rencana disusun disertai dengan deadline sehingga tim memiliki arah dan tujuan yang jelas,

3) Membangkitkan hasrat dan semangat yang murni dan penuh daya gerak untuk mencapai sasaran pribadi dan tim,

4) Mengembangkan rasa percaya diri dan kepercayaan, rasa percaya terhadap anggota tim dibangun, bertumbuh dengan cepat saat pimpinan membagikan pengalaman dan pengetahuannya,

5) Memupuk komitmen dan tanggung jawab, perwujudan upaya tanpa henti, perhatian yang terkendali dan energi yang terkonsentrasi,

6) Mampu menarik, memberdayakan dan memiliki anggota yang loyal,

7) Senantiasa menjadi teladan anggota tim dan 
8) Berani mengambil keputusan dan bertanggungjawab terhadap keputusan.

Pada penilaian fungsi kepemimpinan menggambarkan sikap mengarahkan anggota, memberi masukan, memiliki perhatian, sharing ilmu serta mensosialisasikan tentang patient safety masih dipersepsikan informan Penilaian fungsi kepemimpinan menggambarkan sikap mengarahkan anggota, memberi masukan, memiliki perhatian, sharing ilmu serta mensosialisasikan tentang patient safety. Efektivitas perilaku kepemimpinan Tim dapat dilihat dari:

1) Perilaku yang berorientasi pada tugas dan memandu anggota dalam menetapkan sasaran kinerja yang tinggi tetapi realistis,

2) Perilaku yang berorientasi hubungan dan memperlihatkan kepercayaan, bertindak ramah, perhatian dan memahami anggota,

3) Kepemimpinan yang partisipatif guna memudahkan partisipasi anggota dalam pengambilan keputusan, memperbaiki komunikasi, mendorong kerjasama dan memudahkan pemecahan konflik.

Budaya Keselamatan Pasien merupakan hal yang penting dalam keselamatan pasien. Membangun budaya keselamatan pasien merupakan suatu cara untuk mewujudkan keselamatan pasien secara keseluruhan. Fokus pada budaya keselamatan pasien akan lebih berhasil apabila dibandingkan hanya fokus pada program kesalamatan saja. Budaya keselamatan pasien merupakan langkah awal dalam mewujudkan keselamatan pasien. Budaya keselamatan akan membantu organisasi dalam membuat kebijakan tentang keselamatan pasien.

\section{Pembahasan:}

Keselamatan Pasien Budaya keselamatan merupakan nilal . persepsi dan perilaku yang dianut oleh setiap individu di organisasi. Setiap individu dan grup bertanggung jawab Terhadap keselamatan berprilaku menjaga meningkatkan dan mengkomunikasikan tentang keselamatan, berusaha untuk belajar aktif dari setiap kesalahan yang terjadi . Budaya keselamatan pasien merupakan nilai , kepercayaan, yang dianut bersama dan berkaitan dengan struktur organisasi, kdan sistem pengawasan dan pengendalian untuk menghasilkan norma - norma perilaku. Budaya keselamatan di pelayanan kesehatan diartikan sebagai keyalunan 
, nilai perilaku yang dikaitkan dengan keselamatan pasien yang secara tidak sadar dianut bersama oleh anggota organisasi Budaya keselamatan merupakan bagian penting dalam keseluruhan budaya organisasi yang diperlukan dalam institusi kesehatan Budaya keselamatan didefinisikan sebagai seperangkat kayakinan , norma, perilaku, peran, dan prakcok sosial maupun teknis dalam meminimalkan pajanan yang membahayakan atau mencelakakan karyawan, manajemen , pasien atau anggota masyarakat lainnya. Blegen ( 2006 ) berpendapat persepsi yang dibagikan di antara anggota organisasi ditujukan untuk melindungi pasien dari kesalahan tatalaksana maupun cidera akibas intervenst. Persepsi ini meliputi kumpulan norma standar profesi , kebijakan , komunikasi dan tanggung jawab dalam keselamatan pasien . Budaya ini kemudian mempengaruhi keyakinan dan tindakan individu dalam memberikan pelayanan.

Beberapa Dimensi budaya Keselamatan pasien ( Reason 2012 ) adalah:

1) Kepemimpinan Dalam menciptakan budaya keselamatan pasien dan menurunkan angka kesalahan, diperlukan pemimpin yang menanamkan budaya yang jelas, mendukung usaha pegiwa, dan tidak bersifat menghukum yang disebut dengan kepemimpinan transformasional Budaya keselamatan pasien yang kuat dengan sendirinya akan menurunkan angka kesalahan medis

2) Kerja Sama di Rumah Sakit Tim kerja dapat diartikan sebagai teamwork. Tim kerja merupakan sekumpulan individu dengan keahlian yang spesifik yang bekerja sama dan saling berinteraksi untuk mencapai tujuan yang sama yang membutuhkan komitmen bersama saling percaya dan saling menghormati . Tim adalah sekelompok orang yang bekerja sama dan menghasilkan hasil yang bermakna dalam mengkombinasikan keahlian dan kemampuan masing - masing individu yang menjadi tanggung jawabnya Perawat dapat bekerja sama dengan tenaga kesehatan lainnya seperti dokter dan apoteker dalam keakuratan pemberian obat kepada pasien 


\section{A. Kerjasama Tim}

Kerjasama tim merupakan suatu kelompok kecil orang dengan keterampilan yang saling melengkapi yang berkomitmen pada tujuan bersama , sasaran - sasaran kinerja dan pendekatan yang mereka jadikan tanggung jawab bersama . Kerjasama Tim merupakan bentuk attitude dari perawat dalam bekerja di dalam tim karena membuat individu saling mengingatkan, mengoreksi, berkomunikasi sehingga peluang terjadinya kesalahan dapat dihindari Tim didefinisikan sebagai dua atau lebih individu yang berinteraksi yang memiliki karakteristik yaitu :

a) Memiliki peran spesifik dan interaksi bersama untuk mencapai tujuan

b) Terbentuk untuk membuat suatu keputusan

c) Memungkinkan adanya pendapat yang berbeda untuk mencapai suatu aksi bersama

d) Memiliki keahlian baik pengetahuan maupun keterampilan khusus agar tercapai visi dan misi tim

Tim kerja merupakan bagian dari tim - tim kerja yang merupakan kumpulan individu yang dibentuk untuk mencapai tujuan bersama. Interaksi yang terjadi antar individu dalam tim akan lebih erat daripada pada anggota lain dalam organisasi . Interaksi ini akan membentuk dinamika dalam tim dimana setiap orang akan mempersepsikan perannya dalam tim tersebut dan bertindak sesuai dinamika tim yang ada. Interaksi dalam tim berpengaruh terhadap perilaku anggota dalam berkomunikasi dan terbuka dalam mengungkapkan kesalahan yang terjadi . Adanya kepercayaan di dalam tim bahwa setiap anggota tim bertujuan untuk mencapai kebaikan bersama dan mencari pemecahan yang terbaik dari setiap permasalahan menjadi faktor yang berpengaruh bagi perawat dalam tim untuk memberikan laporan Kesalahan pelayanan yang terjadi. Sebuah tim memiliki tujuan bersama yang ingin dicapai dari hasil kerja secara kolektif, bukan individual . Baik dunia kesehatan maupun bentuk tim secara umum, tim dapat terdiri dari satu profesi yang sama ( contoh : organisasi profesi ), multiprofesi ( contoh : tim gawat darurat ), tim yang bekerja bersama di satu tempat ( contoh : organisasi puskesmas atau RS).terdistribusi secara geografis ( contoh 
kepengurusan nasional ), memiliki anggota yang relatif konstan ( contoh : IDI, PPNI, dil ), dan tim dengan keanggotaan yang berubah ( contoh : pengurus tahunan ).

\section{B. Tujuan Kerjasama Tim}

Tujuan kerjasama tim dan tujuan bersama dalam tim membawa keuntungan karena meningkatkan kinerja . Efek tujuan tim yang jelas paling besar manfaatnya bila terdapat rincian tugas yang jelas pula . Dalam tim juga terdapat tujuan individual dari masing - masing anggota tim . Tujuan pribadi dapat mendorong atau sebaliknya merugikan tujuan bersama tim . Beberapa diskrepansi dari tujuan pribadi anggota dapat dipecahkan dengan mempertimbangkan perbedaan dalam saling keterkaitan. Bila saling keterkaitan rendah, tujuan individu memberi kebaikan karena setiap orang bersama - sama berusaha keras mencapai tujuan tim cara lain untuk mencegah efek buruk dari tujuan pribadi adalah dengan menambahkan tujuan - tujuan individual tersebut menjadi tujuan bersama.

kerjasama tim menentukan kualitas dan mutu pelayanan. Menurut Logan (2014), kerjasama tim merupakan bagian penting dari struktur organisasi perawatan kesehatan untuk memberikan perawatan berkualitas. Secara khusus komunikasi, kepercayaan, dan kepemimpinan dianggap fundamental bagi tim yang efektif. Rumah sakit yang baik yaitu rumah sakit yang mempunyai struktur organisasi dan pembagian tim yang baik dimana kerjasama tim itu sendiri tidak terlepas dari peran seorang pemimpin. Untuk menciptakan kerjasama tim yang efektif hendaknya didasarkan pada kesadaran pada setiap anggota kelompok dalam bekerja, adanya pemimpin yang dapat dijadikan panutan atau contoh bagi anggota timnya dan adanya pembagian peran pada setiap anggota kelompok. Berdasarkan hasil penelitian dan juga beberapa kajian literatur serta penelitian terkait menunjukkan bahwa rata-rata kerjasama tim dipersepsikan baik oleh perawat pelaksana di ruang rawat inap rumah sakit. 


\section{Penutup :}

Budaya keselamatan pasien dikatakan berhasil apabila semua elemen yang ada di dalam rumah sakit menerapkan budaya keselamatan pasien dalam pekerjaannya sehari-hari (Reiling, 2006). Sedangkan Beginta (2012) mengatakan bahwa upaya yang dapat dilakukan untuk meningkatkan budaya keselamatan adalah dengan mendorong setiap orang bertanggung jawab akan keselamatan terhadap diri sendiri, rekan kerja, pasien, dan pengunjung, mengutamakan keselamatan dan keuntungan di atas keutungan dan tujuan organisasi. Weaver et al,. (2013) mengatakan bahwa mempromosikan budaya keselamatan pasien merupakan langkah utama dalam meningkatkan keselamatan pasien. Pemimpin merupakan motor penggerak untuk melakukan aktifitas sesuai dengan yang diharapkan organisasi. Promosi budaya keselamatan pasien yang baik merupakan pelaksanaan dari intervensi yang mendasar dari kepemimpinan yang akan merubah perilaku anggota tim. Sedangkan menurut Nivalinda (2013) Budaya keselamatan yang kuat membutuhkan kepemimpinan yang mampu menetapkan dan mengkomunikasikan visi keselamatan dengan jelas, menghargai dan memberdayakan staf untuk mencapai visi keselamatan pasien. kerjasama tim menentukan kualitas dan mutu pelayanan. Menurut Logan (2014), kerjasama tim merupakan bagian penting dari struktur organisasi perawatan kesehatan untuk memberikan perawatan berkualitas. Secara khusus komunikasi, kepercayaan, dan kepemimpinan dianggap fundamental bagi tim yang efektif. Kerjasama tim merupakan suatu kelompok kecil orang dengan keterampilan saling melengkapi yang berkomitmen pada tujuan bersama, sasaran-sasaran kinerja dan pendekatan yang mereka jadikan tanggung jawab bersama. Kerjasama merupakan bentuk perilaku dari perawat dalam bekerja didalam tim karena membuat individu saling mengingatkan, mengoreksi, berkomunikasi sehingga peluang terjadinya kesalahan dapat terhindari. Dalam hal ini, kerjasama menjadi faktor yang tidak bermakna terhadap implementasi keselamatan pasien oleh perawat pelaksana. 
Saran kepada pihak rumah sakit agar meningkatkan budaya keselamatan pasien terutama dimensi budaya keselamatan pasien yang memiliki persentase respon positif rendah dengan cara memberikan pelatihan intensif mengenai keselamatan pasien kepada seluruh staf. Mengembangkan budaya non punitive/tidak menghukum dengan cara aktif alam melakukan diskusi keperawatan sebagai upaya mencegah kejadian tidak diharapkan dan sebagai upaya mengetahui penyebab manajemen jika terjadi KTD. Membentuk sistem dan alur pelaporan (tulisan dan lisan) kejadian menyangkut keselematan pasien. Menciptakan lingkungan yang membantu staf melaporkan kesalahan secara spontan. Menciptakan suasana komunikasi yang terbuka untuk melaporkan efek samping. Mensosialisasikan mengenai hal-hal terkait keselamatan pasien di setiap instalasi.Melakukan monitoriang dan evaluasi pencapaian dimensi dalam budaya keselamatan pasien. 


\section{DAFTAR PUSTAKA}

Apriningsh., Desmawati., \& Joero, M. (2013). Kerja Sama Tim Dalam Budaya Keselamatan Pasien di RS X (Studi Kualitatif di Suatu RSUD di Provinsi Jawa Barat). Jurnal Ilmiah Keseahatan, 5(3),52-56.

Arini, T.P., Yulia, S., \& Romiko. (2018). Hubungan Kerja Sama Tim Dengan Penerapan Budaya Keselamatan Pasien Di Ruang Rawat Inap Rumah Sakit Bhayangkara Palembang. Jurnal STIKES Muhammadiyah Palembang, 6(2), 406416.

Arini, T. (2018). Budaya Keselamatan pasien Berbasis Pemberdayaan Sturuktual Dengan Kepuasaan Kerja Perawat. Tesis FK UNAIR.

Hadi, I. (2017). Manajemen keselamatan Pasien. Edisi 1 Cetakan 2. Deepublish. Yogyakarta : CV Budi Utama.

Kemenkes RI (2017). Bahan Ajar Keperawatan. Manajemen Keselamatan Pasien. Jakarta : Depkes RI.

Mandriani, E., Hardisman., \& Yetti, H. (2019). Analisis Dimensi Budaya Keselamatan Pasien oleh Petugas Kesehatan Di RSUD dr. Rasidin Padang Tahun 2018. Jurnal Kesehatan Andalas, 8(1),131-137.

Nurlaily, A. P. (2017). Hubungan Komitmen Organisasi Dengan Pencegahan Kejadian Tidak Diharapkan (KTD) Dalam Keselamatan Pasien Di Rumah Sakit Umum Daerah Kabupaten Sukoharjo. Tesis FK UNDIP.

Rivai, F., Sidin, A. I., \& Kartika, I. (2016). Faktor Yang Berhubungan dengan Impelementasi Keselamatan Pasien DI RSUD AJJAPPANNGE SOPPENG Tahun 2015. Jurnal Kebijakan Kesehatan Indonesia, 5(4),152-157.

Simamora, R. H. (2018). Buku ajar keselamatan pasien melalui timbang terima pasien berbasis komunikasi efektif: SBAR. Medan: USUpress.

Simamora, R. H. (2020). Learning of Patient Identification in Patient Safety Programs Through Clinical Preceptor Models. Medico Legal Update, 20(3), 553556. 
Syam, N. S. (2017). Impelementasi Budaya Keselamatan Pasien Oleh Perawat Di Rumah Sakit Ibnu Sina Makassar. Jurnal Fakultas Kesehatan Masyarakat. 11(2),169-174.

Yarnita, Y.(2018). Analisis Hubungan Sikap Perawat Dengan Budaya Keselamatan Pasien DI Ruang Rawat Inap RSUD ARIFIN ACHMAD PROVINSI RIAU. Jurna Photon, 8(2). 81-85.

Yarnita Y., Efitya. (2020). Analisis Faktor Yang Berhubungan Dengan Budaya Keselamatan Pasien Pada Perawat Di Ruang Rawat Inap RSUD Arifin Achmad Provinsi Riau. Jurnal Ilmiah Universitas Batanghari Jambi. 20(3), 827-833. 